\title{
New Challenges for School Psychologists in the Slovak Republic
}

\author{
Eva Gajdosova \\ Pan-European University, Bratislava, The Slovak Republic
}

\begin{abstract}
The article emphasizes the new challenges and tasks of school psychologists going from the European and Slovak health policy to support and safe human and children rights at schools, to give attention to them ental health of pupils and teachers and to their personal and professional development and well-being, to prefer prevention and preventive longitudinale programes with the emphasise upon applied positive psychology, to give great emphasis on the group and comunity counselling and career guidance programes and to the direct and indirect intervention to the educational process, and do not forget on public eduaction, research, medialization, and narrow cooperation with other specialists and experts at schools in the multidimensional teams.
\end{abstract}

Keywords: school psychology, school psychologist, new challenges, mental health

\section{Introduction}

\section{Problems in Slovak Schools of the $21^{\text {st }}$ Century}

The $21^{\text {st }}$ century introduced many positive changes in the Slovak educational system and the system of upbringing and education at nursery, primary and secondary schools in Slovakia, but also many new tasks, problems, crises and challenges. I shall mention just some of the more significant changes (Gajdošová, 2012):

(1) The new school legislation (school acts, regulations, and decrees), the preparation of state educational programmes for nursery, basic and secondary schools, as well as the school educational programmes with the emphasis on mental health at schools, prevention of socially pathological phenomena, the implementation of long-term preventive programmes;

(2) The eminent emphasis on further and life-long education of teachers, psychologists, and other employees and school specialists in particular on the completion of accredited continuous education with credit-awarding and the subsequent reward also in the form of an increase in salary;

(3) The preparation of the standards of professions working at schools, including the standard for school psychologist;

(4) The significant increase in new socially pathological phenomena in school environment (aggression of children, bulling of pupils and teachers, intolerance, racism, xenophobia, drug addiction, non-substance addictions, apathy, resignation, loss of school motivation, loss of sense of life, depression and other psychic diseases, etc.);

(5) The crisis of Slovak family, family care and family upbringing, insufficient cooperation of parents with schools, the increase in aggression of parents against teachers;

Eva Gajdosova, Ph.D., Professor, Faculty of Psychology, Pan-European University. 
(6) The insufficient personal and qualification representation of contemporary schools, not only by teachers, assistants of teachers, but also other experts who are really necessary at contemporary schools (school psychologists, social pedagogues, speech therapists, and special teachers), the significant share of older and old teachers at a pensionable age who cannot deal in particular with the psychological problems of pupils and the problems with their upbringing and cope with the pressure on computer literacy;

(7) Load, stress, and burnout syndrome in a notable number of teachers, as well as other pedagogic employees and specialists caused by the demanding requirements of school management regarding the preparation and keeping the pedagogic documentation, repeated bureaucratisation of schools, the pressure of school management on the continual education of already overloaded teachers (in particular in the field of command of computers), the necessity of obtaining credits for a small improvement of salary, hampered communication and contacts with the parents of pupils, serious problems with upbringing of contemporary pupils, low status of a teacher in Slovakia;

(8) The new proposals of the Ministry of Education, Science, Research, and Sport of the Slovak Republic to inclusive education, which is accompanied with the psychological problems and pressure on the social make-up of both pupils and teachers in the newly-created pupil bodies and teaching staff and related social crises; and

(9) The need for school psychologists at schools and the confirmation of the profession of school psychologist in new school legislation, the pressure on theoretical and practical preparation in university study with subsequent supervision in practice and on the other hand the impossibility of obtaining funds from state budget for their salaries, etc.

These and many other not mentioned changes in the education system are also reflected in the new tasks standing before school psychology as a science and school psychologist as its profession in the $21^{\text {st }}$ century.

We shall try to characterise some fields of problems in detail and at the same time, to formulate on their basis also the task that must be performed in Slovakia in the closest period in connection with school psychology and school psychologist.

\section{Place of School Psychology in the System of Psychological Sciences in the $21^{\text {st }}$ Century}

School psychology has seriously established in the system of psychological sciences with its own special mission, with its own objectives and methods at the beginning of the $21^{\text {st }}$ century and it has attained one of the significant, or even key positions amongst the applied psychological disciplines in the European context.

The newest documents of European Federation of Psychologists' Associations (EFPA) take it as one of three the most significant psychological disciplines alongside clinic and work psychology, as school and educational psychology.

School psychology as a subject is taught at all universities in Slovakia, it has also become the subject of state final examination and the doctoral study curriculum 3.1.11 Pedagogical, counselling, and school psychology.

Challenges: However school psychology needs greater promotion in the media, coordinated research (national and international projects) and more monographs (for example, also in cooperation of employees of several departments and universities in Slovakia or even foreign universities).

\section{Preparation and Education of School Psychologists-Pre-gradual and Post-gradual Study and Life-long Education}

Nowadays, school psychologists are prepared in single-field master study of psychology and also in 2-year 
specialisation education in school psychology after completing two field study of psychology in combination with other subjects.

The requirements of EFPA for the preparation of psychologists and the obtaining of a EuroPsy diploma are demanding nowadays. Within the first stage of the study (bachelor curriculum), the requirements for BC. study at Slovak universities and departments of psychology were fully accepted. The implementation of differentiated Mgr. study of school psychology is considered at universities.

However, the problem is still the $3^{\text {rd }}$ stage in the education of psychologists, as well as school psychologists, thus supervisory practice. As it is suggested by EFPA, the third stage in the education of psychologists consists in the supervisory activity within specialisation and in the field of professional psychology, it takes one year and the graduate shall receive another 60 credits by practising. It takes place either at the institutions or certified private companies providing the services congruent with education and specialisation of the student and guarantees the greater portion of supervision is performed by professional psychologist there or it may be a part of university education as half-independent work at the position of psychologist under the supervision of professionals.

The supervisory practice of school psychologists may have the following form:

(1) Single year of full-time psychological practice after the completion of five-year university study;

(2) Several-month (usually 6-month) full-time practice under the supervision of psychologist arranged by the university before the end of the university study and after the completion of the study the applicant takes part in another full-time 6-month practice; and

(3) Several time sections of psychological practical training performed in practice, in particular within the master study, during which the applicant is psychologically full-time practising under supervision. The time sections make one year in total during the 6-year university study and education.

The success is that the Pan-European University has opened the study curriculum School and Work Psychology within the study field 3.1.9. Psychology at the newly established Faculty of Psychology as in the first university in Slovakia in the academic year of 2012/2013 and they started implementing the continuous education of Supervision for Psychologists and School Psychologists accredited at the Ministry of Education, Science, Research and Sport of the Slovak Republic.

Challenges: In the interest to be awarded the EuroPsy diploma, to seriously prepare supervisory practice for school psychologists and the training of supervisors from the range of experienced school psychologist with several-years experience at school. School psychologists may also complete the doctoral study programme at several Slovak universities in the study field 3.1.11. Pedagogical, counselling and school psychology.

\section{Legislation-Conformation of the Profession of School Psychologist in School Legislation of the $21^{\text {st }}$ Century}

First years of the $21^{\text {st }}$ century were favourable for the confirmation of school psychology and the profession of school psychologist in Slovak school legislation. These are the following acts, regulations, and decrees:

The concept of pedagogical and psychological counselling system of 21 March 2007. This concept speaks of the "school psychologist" as part of the system of pedagogical and psychological counselling services and its more detailed working duties are listed subsequently in Annex 3 to that concept.

The Act of the National Council of the Slovak Republic on upbringing and education (the School Act) of 22 May 2008, The following is written in Article 130: "The other components of the system of counselling and prevention include school psychologist" (Para 3), who "cooperates in particular with family, school, educational 
facility, employers, public administration authorities and civil associations" (Para 4), "school psychologist performs his/her activity at schools or educational facilities" (Para 5).

The Act No. 317/2009 Coll. on pedagogical employees and specialists of 24 June 2009 School psychologist is classified in the category of specialists working at school. The competencies and occupational duty of school psychologist at schools is defined by the act as follows: "School psychologist executes the professional activities within orientation psychological diagnostics, individual, group or mass psychological guidance and counselling, psychotherapy, prevention and intervention for children and pupils with special consideration for the process of upbringing and education at school and educational facilities. He/she also performs the professional activities of psychological advisory in the field of family, partner and other social relations. He/she provides the psychological counselling and consulting to the legal representatives and pedagogical employees of schools and educational facilities He/she prepares the basic data for specialists of advisory facilities".

The amended Regulation of the Ministry of Education of the Slovak Republic No. 1702010 Coll. valid as of 1 May 2010 establishes the qualification preconditions and special qualification requirements for individual categories of specialists and thus also school psychologist in Annex 2, Section I, Part I. Nowadays, the standards of school psychologist profession are prepared.

The National Programme for the Care after Children and Youth for 2008-2015 of the Government of the Slovak Republic. The Government of the Slovak Republic assigns firstly the general task to "create the adequate upbringing, educational, social and material conditions for children and youth and to focus on the healthy personal development of pupils and their psychical health" and subsequently stresses, what is especially important for us, school psychologists, that the problems at schools in the field of social relations in classes, communications with schoolmates or also teachers, acceptance and tolerance of differences in schoolmates, the adequate solutions of conflicts, coping with load and stress, as well as the correct self-study, the selection of suitable learning style, the profession decision-making and the selection of university and study field regarding mental health of children and youth and the quality of their life in the school environment and that are closely related to their successfulness at study, school inability to work and performance, may be competently and highly professionally dealt with by psychologists, in particular school psychologists within the psychological services provided to schools.

Challenges: To require the fulfilment of tasks implied by legislation and the government programme. One of the task is also the increase in the number of school psychologists at schools. Nowadays, we register ca450 school psychologists at 2,500 primary and secondary schools, who are the employees of primar and, secondary schools and other psychologists who work in the Psychological Prevention and Counselling Centres and the Special Pedagogical Counselling Centres and they are sent out to schools from their workplace. Headmasters, teachers and parents are interested in this profession and assess it in a positive manner. However, they search for the funds for including school psychologist to full-time school staffing. The Slovak School Psychology Association must more actively engages in the creation of legislative amendments, qualification criteria, profession and ethic standards and visibly contribute to the control or quality of the provided school and psychological services to schools and educational facilities.

\section{Work Concept of School Psychologist in the $21^{\text {st }}$ Century}

The concept of the work of school psychologist in Slovakia was formulated and accredited at the middle of the 1990s and it corresponded to the problems and tasks of that period. However, the $21^{\text {st }}$ century brought several 
significant changes in the education system, family, upbringing and education of children and thus inevitably requires the modification and establishment of new tasks, activities, and relations of school psychologists at school and in the educational facilities.

Challenges: The modification of the concept of the work of school psychologist for the 21 st century in which it shall be necessary to confirm the following activities in the work of school psychologist:

(1) To work with the entire system of school and its subsystems, thus not only just with the sole problem pupil within prevention, diagnostics and prevention. The subsystems and elements of the system include the parents of students, teachers, classes and groups of students in the classes, social climate and social atmosphere of the school and classes, humanisation of the education process, optimalization of education, proposals of new didactic forms, methods and procedures in education and upbringing of pupils, psychohygiene of education, etc.;

(2) To pay eminent emphasis on the personal development and mental health of pupils and teachers, coping with load and stress in school environment and efficient coping strategies. Therefore, the attention must be paid to all pupils, not only the problematic ones, and to contribute to their healthy personal development and mental health at school in context with the applied positive psychology;

(3) To prefer primary prevention in the work of school psychologist and to place emphasis on the preparation and implementation of various longitudinal preventive programmes, group and mass advisory for parents and teachers, as well as the career guidance and counselling for students and the diagnostics of their professional abilities, skills and interests;

(4) Pay attention to the search for suitable strategies for the solution of latter-day social and pathological phenomena at school, such as cyber bullying, non-substance addictions, psychical diseases of children, in particular depression, anxiety, phobias, as well as intolerance, racism, xenophobia, bullying of teachers, apathy and the loss of sense of life in pupils;

(5) Cooperate when solving problems of upbringing and education of children and adolescents in a more intense way with other experts (counselling and clinical psychologists, school special teachers, speech therapists, social workers, coordinators of prevention, career advisers, pedopsychiatrists, as well as lawyers, mediators, doctors) and create the efficient multidisciplinary teams at schools;

(6) Put emphasis on the psychological work and psychological services for family, parents and wider family environment of the child and to cooperate with parents in the upbringing of children and solving of learning, behaviour, and career guidance problems;

(7) To know assure the crisis management and crisis intervention at schools; and

(8) To prepare for the arrival of children of emigrants, asylum seekers, refugees to our schools, to their quality adjustment and related multicultural tolerance, overcoming of prejudices, stereotypes in our children, parents and teachers.

A brief summary of the most serious tasks standing before school psychologists of the $21^{\text {st }}$ century in the Slovak republic:

(1) To justify the social necessity and economical importance of the profession of school psychologist for the $21^{\text {st }}$ century;

(2) To make the profession of school psychologist visibly through publishing the results of his/her work in psychological journals, popular magazines for parents, as well as through the Slovak School Psychology Association; 
(3) To complete the legislation framework for the activity of school psychologist and his/her position at school;

(4) To elaborate the concept of multidisciplinary cooperation of experts at schools;

(5) To compile and approve the accredited study curricula of pre-gradual and post-gradual preparation of school psychologists;

(6) To prepare the system of life-long learning for school psychologists with the emphasis on new trends in the field of prevention, diagnostics and intervention of school psychological work;

(7) To think out the system of public education regarding the psychological services at schools and the work of school psychologists for the wider public; and

(8) To establish efficient cooperation with foreign countries in the field of school psychology and its profession, namely in science, research, training and education and specific practice of school psychologists at schools and educational facilities.

\section{Conclusion}

The profession of school psychologist has found its stable position in 83 countries in the world over the last 20 years. This is mentioned in the contributions by authors Cook, Jimerson, and Begany (2010); Farrell (2010), and this is also dealt with by the collective of authors in their publication named Handbook of International School Psychology (Farrell, Jimerson, \& Oakland, 2006).

The fact that strong international associations have been established in the field of psychology and its specialisation, school psychology, is a reliable measure of the functionality of the psychological orientation from an international point of view. Psychology, and at the same time also school psychology in the EU is represented by a strong EFPA, school psychology has its international representation also by means of the International School Psychology Association (ISPA).

The introduction of EuroPsy diploma and the standards in the education of psychologists considerably contributed to the standardisation of the professional preparation and education of psychologists in European countries.

EFPA created the professional profile of psychologists working within the education system in Europe with three functions-prevention, diagnostics, and intervention at various levels, individual, group, community, and social. The political intentions of the majority of EU countries are oriented to the timely prevention, creation of preventive multi-professional services and more systematic work with schools as if they were organisations.

In 2010, EFPA granted the permit to issue EuroPsy certificates to the national associations representing psychologists including school psychologists (in Slovakia it is the Slovak Psychological Chamber). The European certificate in psychology (EuroPsy) confirms its holder completed high-quality study in psychology, while it does not replace the national standards.

Also, ISPA introduced the ethical code of school psychologist (Oakland, Goldman, \& Bischoff, 1997), defined the specialisation of school psychology (Oakland \& Cunningham, 1992), recommended the sample programme for the preparation of professionals in the particular profession (Cunningham \& Oakland, 1998) and nowadays provides the international accreditation of study programmes in school psychology. ISPA is of the opinion that the accredited programmes who win the international recognition would be more attractive to the applicants in study and they would facilitate the exchanges of students and teachers within various countries. 
When developing the standards of education of school psychologists, they came from the assumption that all study curricula for school psychology should be terminated by getting the recognised title of the university providing the systematic study curriculum for school psychology.

Several key factors must work in the country so that the profession of school psychologist would find a stable position in it. One of the most important factors is the presence of an active and influential Slovak Psychological Chamber and Slovak School Psychology Association that represent the interests of school psychologists. Subsequently, these associations must fulfil several tasks having the key importance in the definition and promotion of the practice of school psychology. These are in particular the following tasks:

(1) To develop contracts with the government, the ministry of education, and the ministry of health;

(2) To keep a protective hand over school legislation and the confirmation of school psychologist in legislation;

(3) To specify the criteria for the preparation and education of school psychologists and for the accreditation of study curricula;

(4) To introduce the standards for granting certificates and licences to school psychologists;

(5) To publish quality professional and academic periodicals; and

(6) To emphasise the usefulness of school psychology in the offices and the government and to provide for its advertising and edification.

\section{References}

Cook, C. R., Jimerson, S. R., \& Begany, J. C. (2010). A model for predicting the presence of school psychology: An international examination of socio-cultural, socio-political and socioeconomic influences. School Psychology International, 31(4), 438-461.

Cunningham, J., \& Oakland, T. (1998). International School Psychology Association guidelines for the preparation of school psychologists. School Psychology International, 19, 19-30.

Farrell, P., Jimerson, S., \& Oakland, T. (2006). School Psychology Internationally: A synthesis of Findings. In S. Jimerson, T. Oakland, \& P. Farrell (Eds.), International Handbook of School Psychology. London: Sage.

Farrell, P. (2010). School psychology: learning lessons from history and moving forward. School Psychology International, 31(6) 581-598.

Gajdošová, E. (Ed.). (2012). Školskýpsychológ pre 21. storočie. Bratislava: Polymédia.

Oakland, T. D., \& Cunningham, J. L. (1992). A survey of school psychology developed and developing countries. School Psychology International, 13(2), 99-129.

Oakland, T., Goldman, S., \& Bishoff, H. (1997). Code of ethics of the International School Psychology Association. School Psychology International, 18(4), 291-298. 